\title{
PROFIL PROTEIN PADA ORGAN TIKUS (Rattus norvegicus) MODEL DIABETES MELITUS TIPE 2 (DMT2)
}

\section{Profile Protein in Rat (Rattus norvegicus) Organ Type 2 Diabetes Melittus (T2DM)}

\author{
Yohanes Bare ${ }^{1,2}$, Fatchiyah ${ }^{1,2}$ \\ ${ }_{1}^{1}$ Jurusan Biologi, Fakultas MIPA, Universitas Brawijaya, Malang, Jawa Timur, \\ Indonesia \\ 2Pusat Studi SMONAGENES, FMIPA, Universitas Brawijaya, Malang, Jawa Timur, \\ Indonesia \\ *corresponding author: Fatchiyah, e-mail: fatchiya@ub.ac.id
}

\begin{abstract}
Type 2 diabetes mellitus (T2DM) is a metabolic disease caused by insulin resistance. Insulin resistance leads to hyperglycemia. Prolong hyperglycemia caused damaged organ and complication such as nephropathy (kidney), liver and cardiovascular diseases. Meanwhile, resistance insulin inhibits protein metabolism. This study aims to investigate the profile of protein organ kidney, liver and heart in T2DM rat animal model. This research was used rats group T2DM (DM) and normal rats as a control (C). Protein isolated from kidney, heart and liver. Profile profile analyzed by SDS-PAGE. In this study we found has different profile protein between T2DM rats (DM) and control rats (C). Fourty bands protein were found in 6 organs, there were HC 5 bands protein, HDM 8 bands protein, LiC 8 bands protein, LiDM 6 bands protein, KC 7 bands protein, KDM 6 bands protein. This result indicated that has different profile protein in rats group T2DM (DM) and rats control group (C).
\end{abstract}

Keywords: Insulin resistance; hyperglycemia; protein profile; SDS-PAGE; $T 2 D M$

\section{PENDAHULUAN}

Diabetes melitus tipe 2 (DMT2) adalah penyakit metabolik kronik. Kasus penderita DMT2 menjadi suatu masalah global dan terus mengalami meningkat diakibatkan karena urbanisasi, 
penambahan jumlah penduduk dan usia (berisiko pada usia 18 tahun). Menurut data International Diabetes Mellitus Federation tahun 2015 melaporkan Indonesia menjadi negara dengan penderita DMT2 terbanyak dan menempatkan pada peringkat ketujuh dan diproyeksikan akan mengalami peningkatan sekitar 6\% populasi pada tahun 2030 (International Diabetes Federation, 2015; Practice, 2015; WHO, 2016; Wild et al., 2004).

Diabetes melitus tipe 2 (DMT2) ditandai dengan kondisi patologis berupa resistensi insulin yang menyebabkan penumpukan glukosa dalam darah (hiperglikemia). Hiperglikemia di dalam darah menyebabkan gangguan metabolisme dalam tubuh. Hiperglikemia dalam darah menyebabkan kerja organ target jantung dan ginjal dalam tubuh untuk mempertahankan kestabilan kerjanya menjadi semakin berat, akibatnya penderita mengalami komplikasi seperti neuropati, nefropati, retinopati, dan peningkatan risiko penyakit kardiovaskular serta penyakit perifer arteri. Resistensi terhadap insulin yang menyebabkan peningkatan produksi dari gula hati yang dikeluarkan. Gangguan hati yang sering ditemukan pada penderita DMT2 adalah lemak hati atau fatty liver, biasanya (hampir 50\%) pada penderita DMT2 dan gemuk. Jaringan hepar ikut berperan dalam mengatur homeostasis glukosa tubuh. Insulin berperan melalui efek inhibisi hormon tersebut terhadap mekanisme produksi glukosa endogen dalam hati secara berlebihan. Resistensi insulin yang semakin tinggi menyebabkan semakin rendah kemampuan inhibisinya terhadap proses glikogenolisis dan glukoneogenesis, dan berdampak terhadap tingkat produksi glukosa dari hepar (Elaziz et al., 2014; Kahn, 2003; King, 2012; Nolan et al., 2011; Pratley, 2013).

Metode SDS-PAGE merupakan salah metode untuk identifikasi protein berdasarkan berat molekul. Perlu dikembangkan cara pencegahan yang tepat dan akurat melalui penelitian awal dengan cara mengidentifikasi whole protein dari organ (hati, jantung dan ginjal) tikus (Rattus norvegicus) dengan metode SDS-PAGE. Penelitian analisis protein menggunakan metode SDS-PAGE sudah dilakukan Karitas \& Fatchiyah (2013) menganailsis pita protein pada Yogurt hasil Fermentasi Susu Kambing Peranakan Etawa dengan Kultur Tunggal menggunakan 
metode SDS-PAGE, Mahaswari. et al (2010), menganalisis pita protein Lernaea cyprinacea.

Penelitian ini dilakukan untuk menginvestigasi profil protein dari organ (hati, jantung dan ginjal) tikus (Rattus norvegicus) berdasarkan berat molekul menggunakan SDS-PAGE. Hasil penelitian ini diharapkan dapat menjadi sumber informasi penelitian lanjutan dengan memberikan nutrisi sehat (berbasis nutrigenomik) untuk memperbaiki profil pita protein yang hilang maupun yang muncul pada kedua kelompok penelitian.

\section{METODE PENELITIAN}

\section{a Waktu dan Tempat Penelitian}

Penelitian ini dilaksanakan pada bulan Desember 2017 sampai Januari 2018. Lokasi penelitian di Laboratorium Biologi Molekuler, Institut Biosains, Universitas Brawijaya Malang.

\section{b Bahan dan Alat}

Prosedur isolasi protein menggunakan mikropipet, tip, mortar dingin, microtube 1,5mL, sentrifugasi, Chamber untuk running SDS-PAGE (BioRad) dan theromobloc. Penelitian ini menggunakan hewan coba tikus jantan (Rattus norvegicus) strain Wistar dengan usia 2 bulan berjumlah 6 ekor diperoleh dari LPPT Gajah Mada dan diaklimatisasi selama 1 minggu. Enam ekor tikus dibagi menjadi 2 kelompok yaitu 3 ekor kelompok kontrol (C) dan 3 ekor kelompok DMT2 (DM). Pembuatan hewan coba model DM dengan pemberian diet tinggi kolesterol 2 bulan. Kadar kolesterol hewan coba diukur setiap 2 minggu sekali dengan cholesterol stick. Injeksi larutan STZ yang diberikan dengan dosis $25 \mathrm{mg} / \mathrm{kgBB}$ dilakukan secara intravena steralis dengan spuit $1 \mathrm{ml}$ setiap 2 minggu sekali dilakukan pengukuran kadar gula darah menggunakan glucometer stick melalui sampel darah yang diambil dari saluran airmata, Pemberian STZ dihentikan ketika kadar gula darah telah mencapai $200 \mathrm{mg} / \mathrm{dl}$ (Rika \& Fatchiyah, 2017).

Sampel yang diambil adalah organ jantung, hati dan ginjal. Bahan yang digunakan untuk isolasi organ yaitu aquadest, $1 \mathrm{mM}$ PMSF dalam DMSO, 50mM KH${ }_{2} \mathrm{PO}_{4}$ 0,5\% Nonidet P-40. Bahan 
yang digunakan untuk analisis protein dengan metode SDSPAGE Separating gel 12,5\% (30\% total akrilamid, Tris pH 8,8, $10 \%$ SDS, 10\% APS dan TEMED), Stacking gel 3\% (30\% total akrilamid, Tris pH 6,8, 10\% SDS, 10\% APS dan TEMED). Pewarnaan menggunakan Comassie Brilliant Blue (CBB) dan bersihkan CBB menggunakan larutan destaining.

\section{c Surat Kelaikan Etik}

Penelitian ini telah mendapatkan persetujuan Laik Etik oleh Komisi Etik Universitas Brawijaya dengan nomor sertifikat 417KEP-UB Tahun 2015

\section{d Isolasi Protein}

Sampel masing-masing organ jantung, hati dan ginjal ditimbang sebanyak 0,1gr, kemudian dicuci dengan PBS $10 \mathrm{mM}$ $\mathrm{pH}$ 7,4 sebanyak $3 \mathrm{x}$, dilanjutkan dengan homogenasi dalam mortar dingin. Homogenat yang terbentuk ditambah $0,5 \mathrm{~mL}$ buffer ekstrak dan dimasukkan dalam microtube $1,5 \mathrm{~mL}$. Homogenat dalam tabung disentrifugasi pada kecepatan 10.000rpm suhu $4^{\circ} \mathrm{C}$ selama 20 menit, supernatan diambil, diukur konsentrasinya menggunakan nanodrop spektrofotometer UV-Vis. Sampel Protein disimpan pada suhu $20^{\circ} \mathrm{C}$ (Fatchiyah et al., 2011).

\section{e SDS-PAGE}

SDS PAGE diawali dengan menyamakan konsentrasi sampel protein $(15,08 \mathrm{mg} / \mathrm{mL})$ lalu ditambahkan Reducing Sample Buffer (RSB) dan pelarutnya berupa Tris $\mathrm{HCl} \mathrm{pH}$ 6,8. Sampel dipanaskan pada suhu $100^{\circ} \mathrm{C}$ selama 5 menit. Dilanjutkan dengan persiapan separating gel dan stacking gel pada cetakan. Cetakan yang sudah terisi gel dimasukkan ke dalam chamber, dan ditambahkan running buffer dalam chamber. Selanjutnya, Marker dimasukkan sebanyak $7 \mu \mathrm{l}$, sampel $30 \mu \mathrm{l}$ pada tiap sumuran. Untuk memulai running, perangkat elektroforesis dihubungkan dengan power supply 200 volt selama 45 menit. Setelah running selesai, diangkat gel kemudian dicuci dengan aquades dan dituangi larutan staining menggunakan CBB (Commassie Briliant Blue) selama 15 menit, kemudian diganti dengan larutan destaining, proses destaining dilakukan dengan shaker bersama kertas saring, hasil staining divisualisasikan dengan GelDoc. Berat molekul pita protein tersebut ditentukan 
dengan mengukur mobilitas molekul protein dalam gel poliakrilamid berdasarkan kurva standar berat molekul dari protein standar (Fatchiyah et al., 2011)

\section{f Parameter Penelitian}

Dalam penelitian ini parameternya adalah berat molekul pita protein organ yang tersparasi dari hasil SDS-PAGE.

\section{g Analisis Data}

Pita hasil eletroforesis diukur berat molekulnya berdasarkan Rf (Retardation Factor) dengan rumus (Rantam, 2003):

$$
R f=\frac{\text { Jarak pergerakan protein dari tempat awal }}{\text { jarak pergerakan warna dari tempat awal }}
$$

Nilai Rf dimasukkan dalam persamaan regresi linear dengan rumus: $\mathrm{Y}=\mathrm{a}+\mathrm{bX}$ Keterangan: $\mathrm{Y}=$ berat molekul $\mathrm{X}=$ nilai $\mathrm{Rf}$ sampel organ.

\section{HASIL DAN PEMBAHASAN}

Hasil SDS-PAGE berupa pita protein yang tersparasi berdasarkan berat molekul (Gambar 1a yang ditunjuk anak panah). Pita protein yang muncul pada organ kemudian dihitung berat molekulnya dengan rumus Rf. Hasil perhitungan Rf dan log BM pada marker protein 12 pita (Gambar $1 \mathrm{~b}$ ) diperoleh persamaan regresi linear yaitu: $\mathrm{Y}=-1,4654 \mathrm{x}+2,27$ dengan nilai $\mathrm{R}^{2}=0,9519$ (gambar 1c).

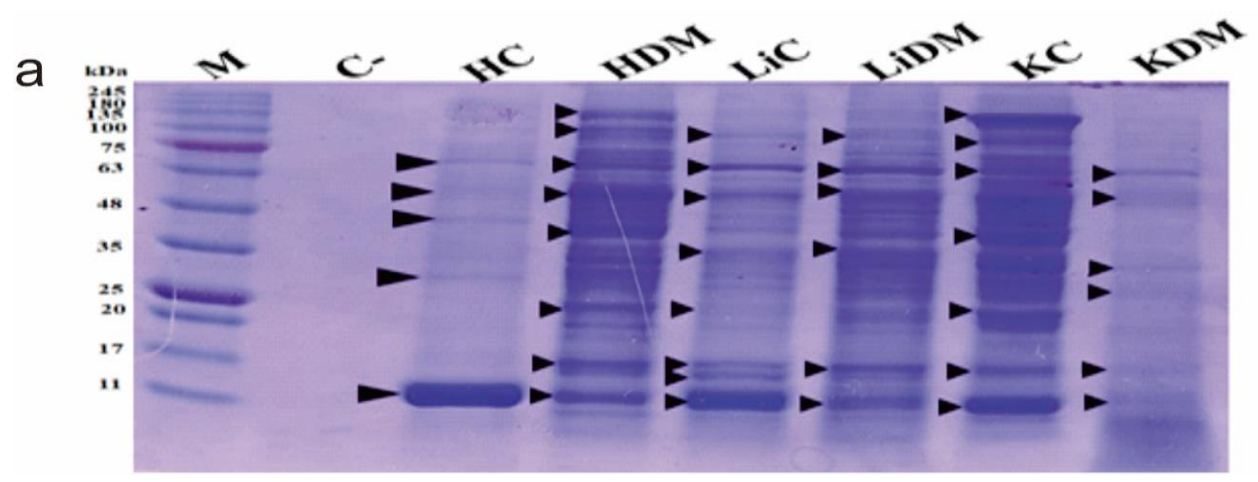




\begin{tabular}{|c|c|c|c|}
\hline $\begin{array}{l}\text { Mw } \\
\text { marker } \\
(k D a)\end{array}$ & $\begin{array}{l}\text { Pergerakan } \\
\text { Protein } \\
(\mathrm{mm})\end{array}$ & Rf & $\begin{array}{l}\text { Log BM } \\
(\mathrm{kDa})\end{array}$ \\
\hline 245 & 0,5 & 0,0556 & 2,3892 \\
\hline 180 & 0,7 & 0,0778 & 2,2553 \\
\hline 135 & 0,9 & 0,1000 & 2,1303 \\
\hline 100 & 1,3 & 0,1444 & 2,0000 \\
\hline 75 & 1,6 & 0,1778 & 1,8751 \\
\hline 63 & 2,4 & 0,2667 & 1,7993 \\
\hline 48 & 3,1 & 0,3444 & 1,6812 \\
\hline 35 & 4,1 & 0,4556 & 1,5441 \\
\hline 25 & 5,3 & 0,5889 & 1,3979 \\
\hline 20 & 5,9 & 0,6556 & 1,3010 \\
\hline 17 & 6,9 & 0,7667 & 1,2304 \\
\hline 11 & 7,8 & 0,8667 & 1,0414 \\
\hline
\end{tabular}

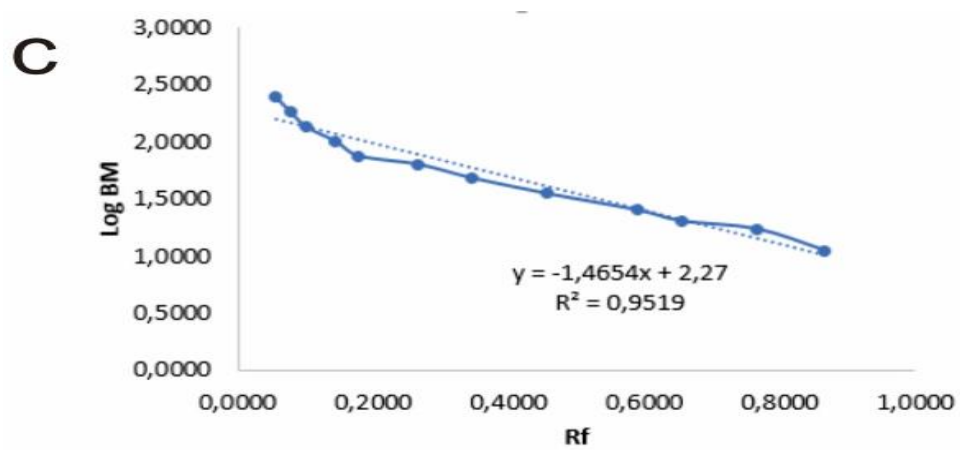

Gambar 1. Profile protein organ menggunakan SDS-PAGE. (a) Pita protein organ tikus (Rattus norvegicus) menggunakan SDS-PAGE (C-=Kontrol negatif, $\mathrm{HC}=$ jantung kontrol, $\mathrm{HDM}=$ jantung DMT2, LiC= hati kontrol, LiDM= hati DMT2, KC= ginjal kontrol, KDM= ginjal DMT2). (b) Tabel Berat molekul protein berdasarkan perhitungan nilai Rf. (c) Grafik Log berat molekul protein organ $y=-1,4654 x+2,27, R^{2}=0,9519$

Pita protein yang tersparasi hasil SDS-PAGE menunjukan adanya persamaan dan perbedaan profil protein dari kelompok kontrol (C) dan kelompok DMT2 (DM). Pada organ jantung ditemukan 5 pita protein pada kelompok kontrol (C) (Tabel 1) dan 8 pita protein pada kelompok DMT2 (DM) (Tabel 4). Pada jantung DMT2 (HDM) terdapat beberapa pita protein yang hilang yaitu protein dengan berat molekul 91,9kDa, 66,1 kDa, 45,4kDa, 23,5 $\mathrm{kDa}$, dan $7,3 \mathrm{kDa}$, sedangkan beberapa protein ditemukan pada jantung DMT2 (HDM) yaitu protein dengan berat molekul $154,1 \mathrm{kDa}, 121,8 \mathrm{kDa}, 83,6 \mathrm{kDa}, 60,2 \mathrm{kDa}, 37,6 \mathrm{kDa}, 16,2 \mathrm{kDa}, 8,8 \mathrm{kDa}$, dan 6,3kDa. 
Profil Protein Pada Organ Tikus...

rabel 1.

Profil Pita Protein Jantung Kontrol (HC)

\begin{tabular}{lccrr}
\hline No & $\begin{array}{l}\text { Mobility } \\
\text { Protein } \\
\text { (cm) }\end{array}$ & Rf & $\begin{array}{l}\text { Rf (a/b) } \\
\text { sumbux }\end{array}$ & $\begin{array}{l}\text { MW } \\
\text { (kDa) }\end{array}$ \\
\hline 1 & 2,1 & 0,2333 & 1,9632 & 91,9 \\
2 & 2,8 & 0,3111 & 1,8204 & 66,1 \\
3 & 3,6 & 0,4000 & 1,6572 & 45,4 \\
4 & 5 & 0,5556 & 1,3715 & 23,5 \\
5 & 7,5 & 0,8333 & 0,8615 & 7,3 \\
\hline \multicolumn{5}{l}{ Keterangan: Panjang $9 \mathrm{~cm}$} \\
\end{tabular}

Tabel 2.

Profil Pita Protein Hati Kontrol (LiC)

\begin{tabular}{lrlrr}
\hline No & $\begin{array}{l}\text { Mobility } \\
\text { Protein } \\
\text { (cm) }\end{array}$ & & $\begin{array}{l}\text { Rf (a/b) } \\
\text { sumbux }\end{array}$ & $\begin{array}{l}\text { MW } \\
\text { (kDa) }\end{array}$ \\
\hline 1 & 1,5 & 0,1667 & 2,0857 & 121,8 \\
2 & 2,3 & 0,2556 & 1,9224 & 83,6 \\
3 & 3 & 0,3333 & 1,7796 & 60,2 \\
4 & 4,3 & 0,4778 & 1,5144 & 32,7 \\
5 & 5,3 & 0,5889 & 1,3103 & 20,4 \\
6 & 7 & 0,7778 & 0,9635 & 9,2 \\
7 & 7,3 & 0,8111 & 0,9023 & 8,0 \\
8 & 7,8 & 0,8667 & 0,8002 & 6,3 \\
\hline \multicolumn{4}{c}{ Keterang }
\end{tabular}

Tabel 3.

Profil Pita Protein Ginjal Kontrol (KC)

\begin{tabular}{lccrr}
\hline No & $\begin{array}{l}\text { Mobility } \\
\text { Protein } \\
(\mathrm{cm})\end{array}$ & & $\begin{array}{l}\text { Rf (a/b) } \\
\text { sumbux }\end{array}$ & $\begin{array}{l}\text { MW } \\
(\mathrm{kDa})\end{array}$ \\
\hline 1 & 1 & 0,1111 & 2,1877 & 154,1 \\
2 & 1,7 & 0,1889 & 2,0448 & 110,9 \\
3 & 2,5 & 0,2778 & 1,8816 & 76,1 \\
4 & 3,9 & 0,4333 & 1,5960 & 39,4 \\
5 & 5,8 & 0,6444 & 1,2083 & 16,2 \\
6 & 7,1 & 0,7889 & 0,9431 & 8,8 \\
7 & 7,9 & 0,8778 & 0,7798 & 6,0 \\
\hline \multicolumn{5}{c}{ Keterangan: Panjang 9cm }
\end{tabular}

Tabel 4.

Profil Pith Protein Jantung DMT2 (HDM)

\begin{tabular}{lrlrr}
\hline No & $\begin{array}{l}\text { Mobility } \\
\text { Protein } \\
\text { (cm) }\end{array}$ & Rf & $\begin{array}{l}\text { Rf (a/b) } \\
\text { sumbux }\end{array}$ & $\begin{array}{l}\text { MW } \\
\text { (kDa) }\end{array}$ \\
\hline 1 & 1 & 0,1111 & 2,1877 & 154,1 \\
2 & 1,5 & 0,1667 & 2,0857 & 121,8 \\
3 & 2,3 & 0,2556 & 1,9224 & 83,6 \\
4 & 3 & 0,3333 & 1,7796 & 60,2 \\
5 & 4 & 0,4444 & 1,5756 & 37,6 \\
6 & 5,8 & 0,6444 & 1,2083 & 16,2 \\
7 & 7,1 & 0,7889 & 0,9431 & 8,8 \\
8 & 7,8 & 0,8667 & 0,8003 & 6,3 \\
\hline
\end{tabular}

Keterangan: Panjang $9 \mathrm{~cm}$

Tabel 5.

Profil Pita Protein Hati DMT2 (LiDM)

\begin{tabular}{cccrr}
\hline No & $\begin{array}{l}\text { Mobility } \\
\text { Protein } \\
\text { (cm) }\end{array}$ & & $\begin{array}{l}\text { Rf }(\mathrm{a} / \mathrm{b}) \\
\text { sumbux }\end{array}$ & $\begin{array}{l}\text { MW } \\
(\mathrm{kDa})\end{array}$ \\
\hline 1 & 1,3 & 0,1444 & 2,1265 & 133,8 \\
2 & 2,1 & 0,2333 & 1,9632 & 91,9 \\
3 & 2,7 & 0,3000 & 1,8408 & 69,3 \\
4 & 4 & 0,4444 & 1,5756 & 37,6 \\
5 & 7 & 0,7778 & 0,9635 & 9,2 \\
6 & 7,8 & 0,8667 & 0,8002 & 6,3 \\
\hline \multicolumn{5}{l}{ Keterangan: Panjang $9 \mathrm{~cm}$} \\
\end{tabular}

Tabel 6.

Profil Pita Protein Ginjal DMT2 (KDM)
No Mobility Rf Rf $(\mathrm{a} / \mathrm{b}) \quad$ MW Protein

sumbux $(\mathrm{kDa})$ (cm)

\begin{tabular}{ccccr}
\hline 1 & 2,5 & 0,2778 & 1,8816 & 76,1 \\
2 & 2,9 & 0,3222 & 1,8000 & 63,1 \\
3 & 4,7 & 0,5222 & 1,4327 & 27,1 \\
4 & 5,3 & 0,5889 & 1,3103 & 20,4 \\
5 & 7,3 & 0,8111 & 0,9023 & 8,0 \\
6 & 7,8 & 0,8667 & 0,8002 & 6,3 \\
\hline \multicolumn{5}{l}{ Keterangan: Panjang 9cm }
\end{tabular}

Pada DMT2 terjadi proses aktivasi protein kinase, aktivasi ini akan meningkatkan pembentukan ROS dalam sel dan 
menyebabkan kerusakan struktural dan fungsional vaskuler sehingga menganggu permeabilitas seluler, memunculkan inflamasi, apoptosis, serta peningkatan produksi endothelin-1 (ET-1) yang akan menyebabkan vasokontraksi dan agregasi platelet. Pada kasus DMT2 dengan kondisi hiperglikemia kronik dan resistensi insulin menentukan perubahan yang signifikan dalam faktor koagulasi seperti peningkatan agregasi trombosit, yang mengarah ke prothromboticstate (Paneni et al., 2013).

Pada organ hati kontrol (LiC) ditemukan 8 pita protein (Tabel 2) sedangkan pada hati DMT2 (LiDM) ditemukan 6 pita protein (Tabel 5). Pada organ hati ditemukan adanya persamaan pita protein yang muncul pada kedua kelompok grup yaitu pita protein dengan berat $6,3 \mathrm{kDa}$. Terdapat perbedaan pita protein pada kedua kelompok, pada organ LiDM menunjukan banyak pita protein yang hilang yaitu pita protein dengan berat $121,8 \mathrm{kDa}$, $83,6 \mathrm{kDa}, 60,2 \mathrm{kDa}, 32,7 \mathrm{kDa}, 20,4 \mathrm{kDa}, 9,2 \mathrm{kDa}, 8,0 \mathrm{kDa}$, disamping itu ditemukan beberapa pita protein yang tekspresi dan muncul pada kondisi LiDM yaitu pita protein dengan berat molekul 133,8kDa, 91,9kDa, 69,3kDa, 37,6kDa, dan 9,2kDa.

Pita protein pada organ ginjal menunjukan adanya persamaan dan perbedaan pada kelompok kontrol maupun kelompok DMT2. Persamaan pita yang muncul pada ginjal kontrol (KC) (Tabel 3) dan ginjal DMT2 (KDM) (Tabel 6) yaitu protein dengan berat molekul 76,1kDa. Pada organ KDM menunjukan ada beberapa pita protein yang hilang yaitu protein dengan berat molekul 154, 1kDa, 110,9kDa, 39,4kDa, 16,2kDa, 8,8kDa, 6,0kDa dan juga ditemukan protein yang hanya dimiliki pada kelompok oran KDM yaitu protein dengan berat molekul $63,1 \mathrm{kDa}, 27,1 \mathrm{kDa}$, 20,4kDa, 8,0kDa, and 6,3kDa.

Gangguan sinyal insulin pada kondisi diebetes nefropati (DN) mempengaruhi fosforilasi protein pada aktivasi reseptor insulin menghasilkan fosforilasi protein kinase B (Akt), yang merupakan protein penting dalam kelangsungan hidup. Protein kinase B (Akt) yang terfosforilasi menunjukan hasil yang beberbeda yaitu Akt yang dihasilkan lebih rendah pada kondisi DN dan peningkatan apoptosis (Filippone et al, 2014; Kambham et al., 2001)

Enam sampel (HC, HDM, LiC, LiDM, KC dan KDM) hasil running SDS-PAGE menunjukan adanya persamaan maupun 
perbedaan pita protein yang muncul. Pita protein yang ditemukan pada kondisi normal mengalami kehilangan pada kondisi DMT2 hal ini berhubungan dengan fungsi protein tersebut dalam metabolisme dalam tubuh. Produk protein yang terdapat dalam organ dalam kondisi normal berhubungan dengan gen yang dikodekan untuk melaksanakan fungsinya, contohnya gen STAT (protein coding) protein dengan berat molekul sekitar 90kDa tidak ditemukan pada kelompok DMT2. STAT1 memiliki fungsi sebagai protein transkripsi (Tadjuidje \& Hegde, 2013; UDN, 2018).

Kehilangan beberapa pita protein disebabkan karena resisten insulin. Pada penelitian ini menggunakan hewan model DMT2 yang patologisnya berupa resistensi insulin. Resistensi Insulin memiliki efek terhadap metabolisme asam amino dan metabolisme protein. Menurut hasil penelitian Menge et al., (2010) pada kasus DMT2 menunjukan defisit beberapa asam amino. Defisit asam amino yang terjadi pada kondisi DMT2 berkontribusi terhadap protein yang terbentuk, sehingga menunjukan pita protein yang berbeda pada DMT2 dibandingkan dengan kontrol. Hasil penelitian Pereira et al., (2008) melaporkan pada DMT2 dengan resisten insulin mempengaruhi metabolisme protein. Resistensi insulin menghambat stimulasi sintesis protein.

Pada kondisi DMT2 menyebabkan metabolisme protein terganggu. Metabolisme protein dan sintesis protein yang terganggu memiliki hubungan dengan protein yang diekspresikan pada kondisi normal maupun kondisi DMT2. Penelitian ini menunjukan adanya perbedaan pita protein yang terekspresi pada kondisi normal dan DMT2.

\section{KESIMPULAN}

Profil pita protein pada kelompok kontrol (C) dan kelompok DMT2 (DM) organ menunjukan profil pita yang sama maupun berbeda. Organ HC ditemukan 5 pita protein sedangkan HDM ditemukan 8 pita protein. Pada organ LiC ditemukan 8 pita protein sedangkan pada organ LiDM ditemukan 6 pita protein. Pada organ KC ditemukan 7 pita protein sedangkan pada organ KDM ditemukan 6 pita protein. Hasil penelitian ini diharapkan menjadi sumber acuan peneliti lanjutan dalam pemberian nutrisi (berbasis 
nutrigenomik) untuk mengembalikan protein yang hilang maupun muncul pada kelompok DMT2 agar dapat kembali pada kondisi normal dalam melaksanakan fungsinya.

\section{UCAPAN TERIMA KASIH}

Penelitian ini di sponsori oleh Hibah Penelitian Unggulan PTN Kemenristek Dikti 2017 Kemenristekdikti dan LPDP Indonesia 2017. Terimakasih kepada Yoga Tribakti Rachmad selama penelitian awal dan Institut Biosains Universitas Brawijaya yang telah menyediakan laboratorium Molekuler.

\section{DAFTAR PUSTAKA}

Elaziz, D. S. A., Hafez, M. H., Galal, N. M., Meshaal, S. S., \& El Marsafy, A. M. (2014). CD4+ CD25+ cells in type 1 diabetic patients with other autoimmune manifestations. Journal of Advanced Research, 5(6), 647-655. https://doi.org/10.1016/-j.jare.2013.09.004

Fatchiyah, Arumingtyas, E. L., Widyarti, S., \& Rahayu, S. (2011). Biologi Molekuler: Prinsip Dasar Analisis. Jakarta: PT Penerbit Erlangga.

Filippone, E. J., Gupta, A., \& Farber, J. L. (2014). Normoglycemic Diabetic Nephropathy: The Role of Insulin Resistance. Case Reports in Nephrology and Urology, 4(2), 137-143. https://doi.org/10.1159/000364901

International Diabetes Federation. (2015). IDF diabetes atlas. Brussels: International Diabetes Federation.

Kahn, S. E. (2003). The relative contributions of insulin resistance and beta-cell dysfunction to the pathophysiology of Type 2 diabetes. Diabetologia, 46(1), 3-19. https://doi.org/10.1007/s00125-002-1009-0

Kambham, N., Markowitz, G. S., Valeri, A. M., Lin, J., \& D’Agati, V. D. (2001). Obesity-related glomerulopathy: An emerging 
epidemic. Kidney International, 59(4), 1498-1509. https://doi.org/10.1046/j.1523-1755.2001.0590041498.x

Karitas, M. U., \& Fatchiyah, F. (2013). Profil Protein 30-60 kDa pada Yogurt hasil Fermentasi Susu Kambing Peranakan Etawa dengan Kultur Tunggal, (2), 5.

King, A. J. (2012). The use of animal models in diabetes research: Animal models of diabetes. British Journal of Pharmacology, 166(3), 877-894. https://doi.org/-10.1111/j.14765381.2012.01911.x

Mahaswari, G., Fajriah, U., \& Subekti, S. (2010). KARAKTERISASI PROTEIN Lernaea cyprinacea DENGAN METODE ELEKTROFORESIS SDS-PAGE. Jurnal Ilmiah Perikanan Dan Kelautan, 2, 62-66.

Menge, B. A., Schrader, H., Ritter, P. R., Ellrichmann, M., Uhl, W., Schmidt, W. E., \& Meier, J. J. (2010). Selective amino acid deficiency in patients with impaired glucose tolerance and type 2 diabetes. Regulatory Peptides, 160(1-3), 75-80. https://doi.org/10.1016/j.regpep.2009.08.001

Nolan, C. J., Damm, P., \& Prentki, M. (2011). Type 2 diabetes across generations: from pathophysiology to prevention and management. The Lancet, 378(9786), 169-181.

Paneni, F., Beckman, J. A., Creager, M. A., \& Cosentino, F. (2013). Diabetes and vascular disease: pathophysiology, clinical consequences, and medical therapy: part I. European Heart Journal, 34(31), 2436-2443. https://doi.org/10.1093/eurheartj/eht149

Pereira, S., Marliss, E. B., Morais, J. A., Chevalier, S., \& Gougeon, R. (2008). Insulin Resistance of Protein Metabolism in Type 2 Diabetes. Diabetes, 57(1), 56-63. https://doi.org/10.2337/db07-0887 
Practice, C. (2015). Update of Mortality Attributable to Diabetes for the IDF Diabetes Atlas: Estimates for the Year 2013. Diabetes Research \& Clinical Practice, 109(3), 461-465. https://doi.org/doi:10.1016/j.diabres.2015.05.037

Pratley, R. E. (2013). The Eraly Treatment of Type 2 Diabetes. The American Journal of Medicin, 126(9), 2-9. https://doi.org/dx.doi.org/10.1016/j.amjmed.2013.06.007

Rantam, F. A. (2003). Metode Imunologi. Surabaya: Airlangga University Press.

Rika, M., \& Fatchiyah. (2017). Influence of CSN1S2 protein from Caprine milk Etawah Breed (EB) on histology of microglial cells in rat (Rattus norvegicus) Type-2 diabetes mellitus (T2DM) (p. 060001). https://doi.org/10.1063/1.5012734

Tadjuidje, E., \& Hegde, R. S. (2013). The Eyes Absent Proteins in Development and Disease. Cell Mol Life Science, 70 (11), 1897-1913. https://doi.org/-10.1007/s00018-012-1144-9

Undiagnosed Diseases Networks. (n.d.). STAT1 Gene: Signal Transducer and Activator of Transcription 1. Retrieved May 26, 2018, from https://www.genecards.org/cgibin/carddisp.pl?gene=STAT1

WHO. (2016). Global Report on Diabetes.

Wild, S., Roglic, S, Green, A., Sicree, R., \& King, H. (2004). Global prevalence of diabetes: Estimates for the year 2000 \& projections for 2030. Diabetes Care, 27, 5-12. 